\title{
CONDUCT OF INTERNAL CONTROL AT THE ENTERPRISES OF THE REPUBLIC OF KAZAKHSTAN
}

Makisheva Zh.A. , Nurpeisova N.S., Kalieva E.V.

Almaty Technological University, Almaty city, Kazakhstan

e-mail: makisheva_zh@mail.ru

Annotation In the article, the authors reveal the role of internal control in improving the efficiency of enterprises, and also substantiates the need to create a national regulatory framework for internal control in accordance with international professional standards. It is emphasized that their implementation will create conditions for improving the activities of internal control and countering risks, developing popular recommendations for the modernization of enterprises' activities, which will ultimately lead to the development of the country's economy. This article discusses the role of internal control in improving the efficiency of an enterprise, also gives a definition of internal control, and sets its objectives. In addition, the article explains the need to implement national professional standards of internal control. An important condition for the effectiveness of the internal control system is the competence and professionalism of its employees, when no employee can commit a significant mistake or unauthorized action without timely detection, which requires further training and skills. employees.

Key words: internal control, system,standards, international professional standards, legal framework, modernization.

Key provisions: The need to create a national regulatory framework for internal control in accordance with international professional standards has been substantiated. Recommendations were developed for the implementation of national professional standards of internal control for the modernization of enterprises.

Introduction.First of all, the management system must promptly develop a number of recommendations to neutralize inefficient operations and carry out work to develop new solutions, then use one of the proposed recommendations to improve business processes that allow solving or overcoming a problem that arose during the management process.

At the same time, in order to prevent negative manifestations from the implementation of business processes, one of the main tasks of any business entity is the timely determination and formation of a detailed list of external and internal risks that affect the efficiency of its activities.

At the same time, an independent subsystem is required in the subject's general management system that is able to assess external and internal risks, respond promptly to their manifestation, anticipate their future occurrence, and, which is especially important, contribute to the creation of a transparent asset management system.

We believe that this subsystem should be control, which is characterized not only by constantly maintained professionalism, but also by a certain set of effective tools that allow one to study a particular problematic situation, develop appropriate effective management recommendations and, in certain cases, predict early manifestations of problems.

To maintain this point of view, it is necessary to rely on the research carried out in this area, the basis of which should serve as theoretical developments and practical activities of control. Internal control is an important management tool for an individual business entity or company to monitor the effectiveness and reliability of corporate governance and risk management systems, as well as to analyze and evaluate the degree to which the company has achieved its goals and objectives [1].

Methodology. Many methods of control methods deserve to be applied in modern conditions. The new economic environment has created an incentive to develop internal control problems in commercial organizations. The foregoing determines the relevance of the study of the methodology, methodology and organization of internal control as one of the main directions for improving corporate governance based on the study of the theory and generalization of the practice of its organization at domestic and foreign enterprises.

In the domestic literature and economic practice of the period of the planned economy, control issues, including internal control, have been extensively developed. The most interesting studies are the works of V.V. Burtsev, S. Brega, O. N. Volkova, N. G. Danilochkina, M. V. Melnik, O. Nikolaeva, V.V. Skobar, JI.B. Sotnikova, V.P. Suits, A.D. Sheremeta, H.I. Fol.muth, P. Croat. They developed a qualitatively new type of internal control internal audit, its interaction with other types of internal control, as well as the methodological apparatus of internal control, taking into account the specifics of pi, exact economics. However, the principle of approach to the internal control of the economic activities of organizations remained the same as that developed in a planned economy.

Results and discussion. Internal control is a safety cushion for carrying out the effective activity of the subject, and also prevents the commission of low-quality and / or illegal, fraudulent operational actions. To implement effective internal control, the leadership of a particular subject at the initial stage needs to carry out analytical work to 
create an internal control system, providing for its integration into all business processes. The substantiation of theoretical provisions was carried out on the basis of the application of such general scientific methods and techniques as systemic and integrated approaches, the method of comparative analysis and synthesis, etc.

An analysis of the world experience in creating individual organizations showed that the idea of building internal control systems for the global business community is not new, since the main approaches to building them were developed more than 20 years ago by the Committee of the Sponsoring Organization of the Treadway Commission (COSO), which is a voluntary private organization, created in the USA, designed to develop appropriate recommendations for corporate leadership on the most important aspects of organizational management, business ethics, financial reporting, internal control, company risk management and anti-fraud. COSO has developed a general model of internal control, in comparison with which companies and organizations can evaluate their own management systems [1].

At the same time, only recently, more attention has been paid to the internal control system in connection with the adoption of the Sarbanes-Oxley law in the USA, which regulates the basic requirements for internal control. Section 404 of the Sarbanes-Oxley Act, "Management and Evaluation of Internal Control", contains a requirement for an audit and management report on the level of functioning of the internal control system. In accordance with these requirements, the management of the companies is obliged to analyze the functioning of the internal control system and document the results obtained from the analysis in the form of an appendix to the financial statements, in which it is necessary to reflect all significant shortcomings of the internal control system with the proposed measures to eliminate them. Then this analysis should be checked by internal and external auditors and the results of the audit together with the annual financial statements should be published. At the same time, the first leaders of the company bear personal responsibility, up to criminal responsibility, for the effectiveness of the internal control system and the reliability of financial statements. For example, if it turns out that the reporting of a certain US company was deliberately distorted, then its head faces a fine of up to 5 million US dollars or a significant prison term [1].

According to the COSO definition, "an internal control system is a process carried out by the board of directors, management and other personnel of a company and / or organization aimed at providing a reasonable guarantee of achieving goals in the following categories: performance, financial statements, compliance with relevant laws and regulations" [2].

Moreover, the internal control system consists of five interconnected components: control environment, identification (identification) of risks, control procedures, information and communication, and monitoring. Each of these components relates to all categories of business goals (strategic, operational, reporting and compliance with legal requirements). After analyzing and summarizing the above components and tasks of internal control, we can give the following definition of the internal control system: "the internal control system is a whole set of interrelated control measures at all levels of management and areas of the company or individual organization aimed at achieving the goals and objectives, maintaining high quality and legal implementation of their functions."

Despite the objective need to create an internal control system, the top officials of some companies in one case do not realize the need for the company to have an internal control system, in the other case they refuse to carry out these complex and costly measures for its implementation. This is because the effect of the implementation of internal control procedures cannot always be obtained instantly and is not always amenable to quantitative and qualitative assessment. The approach to building an internal control system should be based on world standards and meet the requirements of international and national legislation. Moreover, the need to create this system is caused not only by overcoming the negative consequences in the subject's activities from operations illegally and ineffectively performed by the subject, but it is also of a precautionary nature to prevent risks.

The creation of an effective system of internal control is especially important for entities seeking to attract significant amounts of investment. Such organizations need to show that they have organized effective control over the activity as a whole and the implementation of certain operations.

For example, in the Republic of Kazakhstan in the recent past, the National Welfare Fund was created, which plays an important role in attracting investments to the country, creating conditions for investment activity of organizations belonging to the Fund's group, and improving the investment climate in the Republic of Kazakhstan, taking into account the main directions of state policy.

To implement the tasks assigned to the Fund in these areas of activity, its management constantly pays special attention to the creation of an internal control system not only in the Fund itself, but also in subsidiaries. And such examples are not few [3].

In this connection, there is no doubt that the internal control system is necessary not only for organizations included in the Company (Group) with centralized management, but also for an independent legal entity. Since internal control is a process that is constantly carried out by the governing bodies, structural divisions, employees of the organization in the performance of their duties in the quality management of risks, assets and liabilities for the effectiveness and profitability of the organization, including ensuring the safety of assets.

It should be noted that the internal control system must be implemented in all structural divisions and subordinate organizations of the company, without exception. Of course, this will require large costs, a significant part of 
hich may not initially pay off. In this case, it is necessary to carry out work to attract specialists with experience and knowledge of business processes exposed to various risks, who will be able to calculate the costs and benefits of this project. At the same time, the company management should know, and the specialist involved should take into account the consequences of the lack of an internal control system, which are as follows:

- adoption of suboptimal decisions that negatively affect the business of the company;

- high risk of loss of assets;

- difficulty in attracting capital / investment;

- increased risk of misstatement in the financial statements;

- increased risk of fraud;

- unfavorable image of the company.

It should be noted that the created internal control system should allow the organization, company and their employees to continuously identify and assess risks that can adversely affect the achievement of goals and inhibit the solution of tasks.

Undoubtedly, for each company when creating an internal control system, the starting point is the description of business processes in the form of creating provisions, procedures and instructions that determine the procedure for implementing business processes. Moreover, each employee should have an established circle of powers and responsibility for exercising internal control in his activities. An important condition for the effectiveness of the internal control system is the competence and professionalism of its staff, when no employee can make a significant mistake or unauthorized action without it being discovered in a timely manner, which requires further training and skills of employees. Only after carrying out this work, the company can begin to identify risks.

It is important to correctly formulate the control environment of the subject or company, providing for high moral values, honesty, adherence to ethical principles, principles of professional ethics and corporate governance, effective management methods, which, together with legislatively established duties and responsibilities of management and employees, should ensure adequate internal control. Moreover, management bodies are responsible for maintaining an adequate and effective system of internal control, as well as for monitoring the effectiveness of the internal control system. At the same time, it must be emphasized that the effective operation of the internal control system will largely depend on the unit testing the control procedures created by the company.

As a rule, these tasks are assigned to the internal control system. In order for the test results to be objective, this unit must be directly subordinate to either the Board of Directors of the company or the Board of Trustees, or the first head of the entity, that is, its decisions should not be influenced by individual top managers of the company.

- Returning to the internal control system, it should be noted that it is an integral part of the organization's risk management process. Moreover, the subject's risk management is a more extensive process than internal control; it includes and develops an internal control system, transforming it into a more effective form, more focused on identifying and eliminating risks.

- Risk management can be described as the participation of company management in the processes of diagnosis and risk identification, in the selection of corrective, preventive measures, monitoring, control, analysis of the effectiveness of risk management.

- The components of risk management include: the internal environment; goal setting; event definition; identification and identification of risks; risk response; means of control; information and communication; monitoring.

- The internal control system should evaluate the effectiveness and contribute to the improvement of risk management processes. Moreover, the determination of the effectiveness of risk management processes is based on the assessment results of the following categories:

- the goals of the organization are consistent with its mission;

- significant risks are identified and analyzed;

- such measures of response to risks are selected that allow to keep risks within the organization's risk appetite;

- information related to risks is timely recorded and transmitted within the organization, which enables the staff, executive management and the Supervisory Board (Board of Directors, Board of Trustees, etc.) to fulfill their duties.

To justify the risk management assessment, internal control may collect information in several tasks.

A comprehensive analysis of such tasks gives an idea of the nature and effectiveness of risk management processes. Risk management processes are monitored as part of ongoing activities and / or through special assessments or both.

Risk assessment should be carried out in certain areas of the company's activities, as well as in general for the consolidated (main and auxiliary) activities of the company, taking into account all organizations that are subsidiaries or dependent companies.

Thus, the internal control should assess the risks associated with corporate governance, the operating activities of the organization and its information systems, in part:

- taking by the management of the company the necessary and sufficient actions to identify, measure, monitor and control risks;

- the existence of an effective control system, the implementation of decisions; 
- the reliability and integrity of information on financial and economic activities;

- the effectiveness and efficiency of activities and programs;

- safety of assets;

- bringing new operations in line with the approved respective strategies and procedures for their implementation;

- Compliance with the requirements of laws, regulations, procedures and contractual obligations.

Much attention should be given to internal control in assessing the potential for fraud and how the organization manages the risk of fraud. Also, during the implementation of consulting assistance, specialists should take into account risks in accordance with the objectives of the issue, as well as be prepared for the presence of other significant risks.

Helping management to organize or improve risk management processes, employees of the internal control system should refrain from directly participating in the functions of internal control and risk management, which is the responsibility of executive management. The priorities of the internal control system in carrying out its activities are the following competencies: assessment of the effectiveness of the functioning of internal control and risk management systems, as well as proposals for optimizing these systems.

The appraisal measures professionally conducted by the internal control system and the developed highquality and demanded recommendations on their results will allow the company management to provide:

1) improvement of the organizational structure of risk management;

2) the complexity and efficiency of managing all types of risks;

3) optimization of the decision-making system based on the ability to monitor risk in real time;

4) accurate and timely accounting of all risk factors specific to the company's business processes;

5) a clear and timely measurement of all risks (analysis, assessment);

6) conducting a quantitative, qualitative and cost risk assessment;

7) increasing the image of the reputation and attractiveness of the company;

8 ) increasing the level of protection of the interests of investors and company management, etc. [4].

Today, an effective internal control system with risk management functions, an integrated risk management system, coupled with professional internal control, are becoming an instrument of the company's effective activity, and also allow it to successfully develop and compete in the market.

Having analyzed the regulatory framework governing the implementation of measures by internal control systems of a number of Kazakhstani business entities, it was revealed that some of them use various internal regulatory documents governing internal control. At the same time, some of these internal regulatory documents contain the stages of internal control, consisting of planning, internal control, reporting, monitoring, working documentation, others except the stages of internal control, contain an assessment of the performance of employees of the internal control service, etc.. Whereas further improvement of internal control requires the development of regulatory acts of a new format related to the harmonization of regulatory acts existing in foreign countries.

In this regard, there is an objective need for the creation of common professional standards of internal control based on international professional standards of internal control, which will allow bringing internal control to a new level of work in countering risks, assessing financial stability, and developing demanded recommendations for the modernization of enterprises in Kazakhstan, which ultimately entail the development of the country's economy.

Conclusions.Based on the study, it can be concluded that for the effective operation of the management system, a subsystem such as an internal control system is necessary. Thanks to the internal control system, it is guaranteed that goals are achieved in such categories as: performance, financial statements, compliance with relevant laws and regulations. However, it should be noted that the heads of organizations do not pay due attention to the development of an effective internal control system, since the creation of this system does not immediately bring results. Also, there are no uniform national standards of internal control, as a result of which different organizations use different regulatory acts. Solving these problems arising in the development of internal control will help organizations take work on countering risks and assessing financial stability to a new level.

\section{References:}

1 Dmitrienko I.H. Methods of examination and audit diagnostics of the financial condition of a joint venture // Accounting. 1993, no. 9, p. 17-20.

2 Daderkina E.N. Cost accounting and cost calculation in telecommunication companies // Accounting. 2000. - No. 20 - pp. 32-35.

3 LeimapYa.A. Management by results: Per. from Finnish. -M .: Publishing group "Progress", 1993.- 320 p.

4 Glushkov E.I. Management accounting at a modern enterprise. - M .: "KnoRus"; Novosibirsk: "Ecorkniga", 2004, - 160s.

5 Strategic development plan 2050. https://strategy2050.kz/ru/news/52799/ 


\title{
ҚАЗАҚСТАН РЕСПУБЛИКАСЫНЫН КӘСІПОРЫНДАРЫНДА ІШКІ БАҚЫЛАУ ЖУРГІЗУ
}

\author{
Макищева Ж.А. *, Нурпеисова Н.С.,Калиева Е.В.
}

Алматы технологиялық университеті, Алматы, Қазақстан

e-mail:makisheva_zh@mail.ru

Түйін.Мақалада авторлар кәсіпорындардың тиімділігін арттырудавы ішкі бақылаудың рөлін ашып көрсетеді, сонымен бірге халықаралық кәсіби стандарттарва сәйкес ішкі бақылаудың ұлттық нормативтік базасын құру қажеттілігін негіздейді. Оларды жүзеге асыру ішкі бақылау қызметін жақсартуга және тәуекелдерге қарсы тұрува, кәсіпорындардың қызметін модернизациялау бойынша танымал ұсыныстарды әзірлеуге жавдай тувызады, бұл ел экономикасының дамуына әкеледі деп атап көрсетілген. Бұл мақалада кәсіпорын қызметінің тиімділігін арттырудавы ішкі бақылаудын рөлі талқыланады, сонымен қатар ішкі бақылауда анықтама беріледі және оның міндеттері құйылван. Сонымен қатар, мақалада ішкі бақылаудың ұлттық кәсіби стандарттарын енгізу қажеттілігі түсіндіріледі.Іикі бақылау жүйесі тиімділігінің манызды шарты - оның қызметкерлерінің құзыреттілігі мен кәсібилігі, бұл кезде бірде-бір қызметкер елеулі қателік жібере алмаса немесе рұқсат етілмеген іс-әрекетті уақытылы анықтамай жасай алмаса, бұл қосымша дайындық пен біліктілікті қажет етеді. қызметкерлер.

Түйіндісөздер:ішкі бақылау, жүйе, стандарттар, халықаралық кәсіби стандарттар, заңнамалық база, модернизачия.

\section{ПРОВЕДЕНИЕ ВНУТРЕННЕГО КОНТРОЛЯ НА ПРЕДПРИЯТИЯХ РК \\ Макишева Ж.А. *, Нурпеисова Н.С., Калиева Е.В.}

Алматинский технологический Университет, г.Алматы, Казахстан e-mail:makisheva zh@mail.ru

Резюме. В статье авторы раскрывают роль внутреннего контроля в повышении эффективности деятельности предприятий, а так же обосновывает необходимость создания национальной нормативноправовой базы внутреннего контроля в соответствии с международными профессиональными стандартами. Подчеркивается, что их внедрение создаст условия для совершенствования деятельности внутреннего контроля и противодействия рискам, выработки востребованных рекомендаций для модернизации деятельности предприятий, что в итоге повлечет за собой развитие экономики страны. В данной статье рассматривается роль внутреннего контроля в повышении эффективности деятельности предприятия, также дается определение внутреннему контролю, устанавливаются его задачи. Кроме того, в статье объясняется необходимость внедрения начиональных профессиональных стандартов внутреннего контроля.Важным условием эффективности системы внутреннего контроля является компетентность и профессионализм ее сотрудников, когда ни один сотрудник не может совершить существенную ошибку или несанкиионированное действие без своевременного обнаружения его, что требует дальнейшего обучения и навыков сотрудников.

Ключевые слова: внутренний контроль, система,стандарты, международные профессиональные стандарты,нормативно-правовая база, модернизачия.

\section{МРНТИ 68.47.75 \\ УДК 631.1}

https://doi.org/10.51579/1563-2415.2021-1.14

\author{
IMPROVING THE PROCESS OF COST OPTIMIZATION IN AGRICULTURAL \\ COOPERATIVES OF THE REPUBLIC OF KAZAKHSTAN \\ A. Nurtayeva, "B. Gussenov, M. Alekbaeva, A. Saparova \\ «Zhetysu University n.a. I. Zhansugurov» NP JSC \\ Taldykorgan, Kazakhstan \\ e-mail: king bara@mail.ru
}

Summary. The international advanced method of cost accounting used in the main branches of agriculture is based on the generalization of costs for technological processes related to the stages of work provided for by the production technology in crop and livestock production, and can be described as a process-by-process approach. The article considers that the successful solution of the problem of increasing the efficiency of cooperation, the organization of procurement and supply and marketing structures of the agro-industrial complex and the improvement of accounting in them is the most important factor in the stabilization and development of the economy in the new economic conditions. The article discusses the main directions of development of agricultural cooperatives. The process of cost optimization at agricultural enterprises of the Republic of Kazakhstan is considered. The main ways to improve the management system of the cost optimization process in agricultural cooperatives of the Republic of Kazakhstan are outlined. 